\title{
Impact of Motivation on Students' Retention in Public Secondary Schools in Rorya District,
}

\section{Tazania}

\author{
Philimini Philemon, Demetria Gerold Mkulu
}

\author{
Department of Educational Foundation, St. Augustine University of Tanzania, Mwanza, Tanzania \\ Received: 07 Nov 2020; Received in revised form: 10 Dec 2020; Accepted: 18 Dec 2020; Available online: 30 Dec 2020 \\ (C)2020 The Author(s). Published by Infogain Publication. This is an open access article under the CC BY license \\ (https://creativecommons.org/licenses/by/4.0/).
}

\begin{abstract}
Motivation is the heartbeat to students' retention. It keep learners active and alive to remain at school until completion. Students who join secondary education have diverse needs as they come from diverse walks of life. Therefore, motivation stimulate them while at school by meeting their diverse personal needs. This study aimed at exploring the impact of motivation on students' retention in Public secondary schools in Rorya District, Tanzania. The study was based on Maslow's Hierarchy of needs theory of motivation. The study adopted a mixed research approach and an explanatory sequential design. The sample sizes of one hundred and twenty six $(n=126)$ respondents obtained through stratified random sampling, purposive, snowball and simple random sampling techniques were involved. Questionnaires, unstructured interviews and a document review checklist were used to collect data. Validity and reliability were checked. The result of test-retest was 0.87. The validity of the tools was assured by sending tools to education foundations research experts. Therefore, the instruments were valid and reliable. Data were analyzed through descriptive statistics with the help of SPSS version 20 and content analysis approach. The findings indicated that motivation greatly influence secondary school students' retention. The study recommended that, the teachers and all educational stakeholders should actively participate in the motivation of students to continue with the school by ensuring a safe, active parenting role as well as supportive and conducive environment for a student successful completion of his or her studies. Students' need care, love, and respect to remain at school until completion.
\end{abstract}

Keywords-Motivation, Retention, Public secondary schools.

\section{BACKGROUND TO THE STUDY}

Motivation is the force that directs students to achieve their anticipated goals for schooling (Solak, 2012). It refers to any situation which gives the energy to direct and sustain the behaviour (Yilmaz et al., 2017). It is the force whether internal or external which drives an individual towards the accomplishment of the predetermined goals. For learners to achieve their educational goals, they should be very much engaged in school and complete their education cycle. Therefore motivation is one of the major factors which are tremendously required to ensure retention among public secondary school students'. Retaining students in school until they complete is one of the significant indicators of school effectiveness (Crosling, 2017). For instance in Turkish secondary schools many students are unmotivated by issues such as lack of autonomy, less freedom of choice which results in dissatisfaction and lesson disengagement among students(Tasgin \& Tunc, 2018). Students who lack freedom and autonomy in school find school boring most of the time and if there is no intervention to cure the situation they are likely to leave school most of the time. Also, Akay (2017) argues that teaching is not healthy and meaningful without motivation. In this case, motivation is the most important ingredient to stimulate learners to participate actively in the teaching 
and learning process. Sometimes there are recluse students who are shy and inactive and do not confidently participate in the classrooms; if they couldn't get motivation through teachers' support they are likely to be left behind and they can even depart from school (Tasgin \&Tunc, 2018). Students with low motivation feel desperate and are reluctant to learn (Cylan et al., 2016). The study was done by Krsticet al., (2017) in Serbia indicates low motivation for learning being one of the reasons associated with the issue of dropout among students. They argued that "truancy is one of the first signs of drop out and one of the indicators of low motivations for learning".

In the United States of America(U.S.A) studies established that only 35 percent of students dropped out of school due to failure, whilst 69 percent stated lack of motivation as the main reason (Bridgeland et al as cited in Krstic et al., 2017). Moreover, Lockett and Cornelious (2015) in their study done in Mississippi, U.S.A. signified that school dropout is a serious problem in Mississippi. Furthermore, they identified negative experiences students face while in school as the major reason for early school leaving among students. Similarly, Fan and Wolters (2014) in their study on school motivation and high school dropout in the U.S.A indicated that students who drop out of school have low motivation, with a low level of autonomy, and perceived themselves as being less competent at class activities and they don't trust their academic abilities and as the result, they drop out of school. This indicates that even in America where schools are well funded, and supplied with adequate resources quite a large number of students leave their studies due to lack of motivation toward studies. Also, Soilemetzidis and Dale (2013) in their paper concerning students retention in the United Kingdom (UK) argued that students retention is a worldwide issue and attrition is the subject area; they continued saying that, the nature of teaching and learning environment at school and home, as well as personal circumstances such as financial difficulties, demotivate students hence their departure from school.

In the African context students' attrition has been a longtime challenge as the continents fight against ignorance. Kurebwa and Wilson (2015) in their study done in Zimbabwe, contends that the absence of motivation on the side of parents and pupils is likely to result in poor academic performance and pupil dropout. Relatively, Adam, Adom, and Bediako (2016) emphasized this by arguing that, many students in Ghana are at risk of dropping out of school due to a low standard of living, poverty, and lack of motivation.
Moreover, Raymond and Legeso (2017) in their study on contributing factors to learners drop out in public schools in Ngakamodri-Molema District; South Africa signified that low motivation is one of the reasons for learners' attrition. In their study, they demonstrated that dropout was high as students transfer from one grade to the other whereby about 72 percent of learners in grade ten drop out in selected schools as compared to grade eleven with 20 percent and twelve 8 percent.

In East Africa researchers such as James, Simiyu, and Riechi (2016) and Kipyego (2016) claim that, although learners are important stakeholders in education; their retention in Kenyan secondary schools is quite a challenge whereby despite an increase in enrolment, retention remains to be very low. Also, Samuel et al. (2017) maintain that despite the government efforts of trying to retain students through the introduction of Free Day Secondary Education (FDSE) the dropout problem is still persistent in the country.

In Tanzania, the Basic education statistics report (BEST), (2011) shows that in the year 2007 a total of 448,448 students joined secondary school but it was only a total of 190,186 students who were able to complete ordinary level of secondary school in 2011 and this shows that 258, 262 had dropped out of school in three years (Ouma et al, 2017). However as the case of Kenya, the government in 2016 adopted the Free Education Policy which was based on the 2014 Education and Training policy which provided 10 years of free and compulsory primary and lower secondary education starting from January 2016; however, despite those efforts by the government, there are several challenges which impedes students from getting an education (Orotho, 2014; Human Rights Watch, 2017). Since the introduction of free education, the enrolment rate had increased tremendously among lower-level public secondary schools but the rate of completion seems to be low with many of the students withdrawing from school. In their study in Nyarugusu villageGeita region, Ouma et al., (2017) argued that loss of interest and motivation is one of the factors which influenced students to drop out. In their study, they revealed that one hundred and thirty-six (136) male and sixty-four (64) female respondents dropped out of school due to a loss of interest in education.

Furthermore, the Ministry of Education Science and Technology (MoEST, 2016) contends that the low retention rate is highly experienced in the ordinary level of secondary education, form two being the leading class and among the top leading regions in higher dropouts are Mwanza, Tanga, 
Geita, Tabora, Mtwara and Mara respectively. Additionally, The World Bank (2017) contended that however improvements are made in the provision of education in Tanzania, students' retention rate remains low with a retention rate of 51 percent in primary and 65percent in lower secondary level due to high dropout rates among students.

Unfortunately, researchers have not paid much attention to the impacts of motivation on students' retention in public secondary schools. This study, therefore, investigated the impact of motivation on students' retention in Rorya District public secondary school.

\section{Statement of the Problem}

Students' retention is a critical problem facing many educational institutions. The priority of fee-free education in Tanzania is to ensure equitable participation and completion of basic education for all (MoEST, 2018). The available evidence shows that many of the students who join form one each year do not reach form four as many of them drop out of school due to a variety of reasons. Kinisa (2019) indicated that the problem of low retention in Tanzania is persistently triggered by several challenges such as truancy and lack of school necessities. The researcher was asking why there is a high turnover of students while schooling in Tanzania is free. It is in this regard therefore the study wanted to find out the impact of motivation on students' retention.

\section{RESEARCH METHODOLOGY}

This study adopted a mixed research approach and a sequential explanatory research design. A sequential explanatory research design isa mixed research approach design that begins with the gathering of quantitative data first and then qualitative data for the explanation of the quantitative findings (Subedi, 2016).In doing this study the researcher used explanatory research design in data collection whereby the researcher went to the field twice; the quantitative data collection phase and qualitative data collection phase.

A target population is the group of individuals or organizations sharing common characteristics that the researcher can identify and study (Creswell, 2012). The target population for this study included District Education Officer, Ward Education Officer, Head of Schools, Teachers, Students, and Parents.

\section{Sample Size and Sampling Procedures}

The total sample size of this study was one hundred and twenty-six $(n=126)$ respondents where100 respondents were derived from Slovin's formula while nine (9) participants were drawn from the purposive sampling and 17 respondents were found through snowball sampling technique.

\section{Research instruments}

The researcher collected data through a questionnaire, interview guide, and document review checklist.

\section{FINDINGS AND DISCUSSIONS}

This section presents the research findings on the influence of motivation on students' retention, motivational challenges and the strategies to be adopted in ensuring students' retention until completion of their studies.

\section{Demographic Information of the Respondents}

This segment presents background information of the teachers and students which were vital for interpretation of the study findings. The demographic information explored in this study included students' gender, students' class level, teachers' gender, and teachers' working experience at the current work station.

\section{Students' Demographic Information}

The section presents findings on the demographic variables of the students. The results are shown in Table 1.

Table 1: Demographic information of students $(n=76)$

\begin{tabular}{lll}
\hline Variable & Frequency & Percent \\
\hline Gender & & \\
Male & 38 & 50 \\
Female & 38 & 50 \\
Total & 76 & 100 \\
Class level & & \\
Form I & 16 & 21.1 \\
Form II & 20 & 26.3 \\
Form III & 20 & 26.3 \\
Form IV & 20 & 26.3 \\
Total & 76 & 100 \\
\hline
\end{tabular}

\section{Source: Field Data (2020)}

Table 1 presents the demographic information of students who were involved in this study. A total of 76 students were involved in the study with 38 females and 38 males being presented. The study had an equal number of female and 
male students having adopted stratified random sampling techniques whereby they were divided into stratum basing on their gender and randomly selected to ensure the equal presentation of each gender. This gave 50 percent participation for each gender.

The class level of the participants was vital in this study as it gave the researcher chance to accumulate enough details on the impact of motivation on student retention from each class. Table 1 portrays information on the number of students involved in each class from I-IV. The findings demonstrated that students from all classes are vulnerable to motivational challenges resulting in early school withdrawal. Regarding this, the researcher's involvement in all classes was of paramount importance as the engagement gave the researcher a clear picture of motivation and retention from each class level in public secondary schools.

\section{Teachers' Demographic Characteristics}

This section presents findings on the demographic variables of the teachers. The results are shown in Table 2.

Table 2: Demographic Information of teachers $(n=24)$

\begin{tabular}{lll}
\hline Variable & Frequency & Percent \\
\hline Gender & & \\
Male & 18 & 75 \\
Female & 6 & 25 \\
Total & 24 & 100
\end{tabular}

Experience

$\begin{array}{lll}1-5 \text { years } & 6 & 25 \\ \text { 5-10 years } & 13 & 54.2 \\ \text { 10-15 years } & 5 & 20.8 \\ \text { Total } & 24 & 100\end{array}$

\section{Source: Field Data (2020).}

This segment presents background information of the teachers which was vital for interpretation of the study findings. As shown in Table 2 a total of 24 teachers were involved in the study with 75 percent males and 25 percent females. The study found that there is a great gender imbalance in rural public secondary schools as the number of male teachers is bigger than that of female teachers to the extent that some schools have no even one female teacher hence affecting girl student's motivation to continue with school.

Teachers are important stakeholders in the school setting. They require experience to effectively perform their respon- sibilities in molding learners. Experienced teachers who had spent more years in their current work stations would have better strategies to motivate a student to remain in school until the completion of his or her study cycle. The findings demonstrated that a total of 25 percent of teachers worked for between 1-5 years in their current stations while 54.2 percent of teachers worked for 5-10 years and 20.8 percent worked for between 10-15 years. From the findings, it was revealed only 54.2 percent of teachers have good experience concerning their students leaving the majority of others less experienced thus, making it difficult for them to deeply understand and take into account the needs and background of each learner. Berger et al. (2018) supported the idea arguing that the more experience the teacher had, the more they could allow learners to decide and try what they wish. They added that experienced teachers foster student retention at school. This means that the more a teacher stays at the current school the more he or she could understand his or her student's motivational needs.

\section{Research Question One}

The first research question was to ascertain whether motivation affects students' retention in Public secondary schools in Rorya District. This research question called for testing of a null hypothesis which states:

There is no significant relationship between motivation and students' retention.

The hypothesis was tested by the Pearson Product Moment Correlation Coefficient as can be seen in Table 3 .

Table 3: Correlation between Motivation and students' retention.

$\begin{array}{llll}\begin{array}{l}\text { Students' reten- } \\ \text { tion }\end{array} & \begin{array}{l}\text { Pearson Correla- } \\ \text { tion }\end{array} & 1 & .363^{*} \\ & \text { Sig.(2-tailed) } & & .000 \\ & \mathrm{~N} & 100 & 100 \\ & & & \\ & \begin{array}{l}\text { Pearson Correla- } \\ \text { tion }\end{array} & .363^{\text {* }} & 1 \\ & \text { Sig.(2-tailed) } & .000 & \\ & \mathrm{~N} & 100 & 100\end{array}$

**. Correlation is significant at the 0.01 level (2-tailed).

Source: Field Data (2020). 
The major findings indicated that motivation greatly influences students' retention in public secondary schools. The findings on the effect of motivation on students' retention were as follows;

\section{Motivation boosts students' school attendance rate}

The results from open-ended questionnaires administered to the students, teachers, and parents as well as all the interviewees revealed that motivation encourages students to keep going to school on regular basis. Indeed, most of the students responded that they are more likely to continue with school in an attractive and supportive learning environment. Students claimed that school safety increases their attendance, engagement, and participation as it makes them more motivated and comfortable while at school. In addition to that, they claimed that the presence of safety on their way to school; positive teacher-student relationships, and availability of food at school are the ingredients that boost their interest to attend school regularly. For instance, one student wrote that "the presence of lunch program at school acts as a catalyst which increases students' school attendance rate". This means that a safe and supportive learning environment is very important to increase attendance and school retention rate among students. Similar claims were made by teachers, insisting that when students are assured of their physical, mental, and emotional safety on their way to school and at school, their attendance rate advances. Correspondingly, all interviewees were of the view that students' safety matters when it comes to their retention at school, accentuating that it is hard for a learner to continue with school in an area full of threats and intimidation. They pointed out that the availability of motivating factors such as supportive learning facilities, food, safety, care, and recognition greatly encourages students to avoid attrition from school. Once more, all parents emphasized that the availability of a supportive environment at school encourages students to attend school and reduces truancy. This has been emphasized by Interviewee 1 (HoS) stating that "motivation reduces truancy and absenteeism among students and increases their interest and determination to finish school" (Interviewee1, August 27, 2020). This finding is consistent with that of Maijo (2018) in his study in Mlunduzi ward. As a result, Maijo demonstrated that motivation promotes regular attendance among students. Moreover, Mwendwa and Gori (2019) in Kitui County, Kenya underlined similar views on how motivating factors such as school feeding program promotes students' regular school attendance. This also incurs the conceptual framework in the sense that motivation attributes to improved school attendance and students' active participation.

\section{Motivation directs students toward the realization of their goals}

The majority of the participants who participated in this study are of the view that motivation influences retention among students by creating an opportunity for each learner to have a chance to grow toward their full potential. Most students pointed out that the availability of motivating factors such as sport and game facilities, enough laboratory apparatus, books, and other facilities at school provides a guiding frame for students' realization of their full potential. Emphasizing this one student wrote that, "Availability of supportive science teachers at this school influences me to remain here as my dream is to become an engineer in the future". This implies that students are motivated to retain at certain schools when they find the school environment supportive toward the realization of their full potential. Emphasizing this aspect Interviewee 7 (HoS) commented that, "motivation raise student retention rate as it drives students' energy toward their full potentiality" (September 3, 2020). Correspondingly, Kahu et al. (2017) in their qualitative study in Australian universities emphasized this arguing that pertinent students' interest and future professional goal is significant to students' accomplishment and retention. They further elaborated that when students do what is essential and attached to their future profession they become more engaged in class hence their retention in school. Furthermore, Neto (2015) supported the idea arguing that self-actualization needs are crucial in motivating students' retention toward their academic achievement as students receive immediate satisfaction when appealing to an activity for their inner personal goal. Adding to this Ozaslan (2018) argued that supporting students' walk toward their full potential is an obvious foundation for contentment and commitment to the school. The idea incurs with Maslow's hierarchy of needs theory stressing that self-actualization need triggers students' desire to continue with school so that they could fulfil their inner desire and dream in life.

This means that students' decision to retain at a certain school is influenced by the support a learner receives in a move toward her or his desire in life. This implies students' retention at school is the result of the motivation given by the teachers and the school community in their journey to becoming what they wish to be in the future. 


\section{Motivation boosts students' confidence}

All respondents and participants who participated in this study were of the view that motivation develops students' confidence in themselves, their teachers as well as on their school. The respondents further argued that motivation develops students feeling of trust and confidence in their teachers and the school in general. Elaborating this, one of the students wrote that, "Motivation creates a confidence and trust-based atmosphere for teachers and students to interact and share ideas comfortably and freely". Supporting this Khun-Inkeeree et al. (2017) in their study done in Southern Thailand argues that the cooperative and interactive relationship between teachers and students is a central block for students' retention. Emphasizing this aspect, most teachers commented that a sensitive and supportive school environment creates students' sense of confidence toward their school hence their retention until graduation. Supporting this Oke et al. (2016) in their study done in Ogun state, Nigeria stressed this arguing that students' confidence in school increases when they feel motivated. This is in line with the conceptual framework which indicated that motivation lift students' confidence and self-esteem.

This finding implies that motivation increases students' confidence which is very essential in developing students' level of engagement and retention at school. Thus, the more a student is confident in the school and the working staff supporting him or her the more likely that they could remain there until the completion of the study time.

\section{Motivation creates a sentiment of perseverance among students}

After an intensive analysis of the findings, it was revealed that the majority of the respondent indicated that motivation contributes to students' retention at school. Responses to the open-ended questionnaires demonstrate that motivation increases learners' determination and commitment to complete school. Undeniably, the findings pointed out that motivation makes students more determined and focused toward completion of their studies weighting that motivated students could not easily quit school as they find themselves supported, encouraged, valued, recognized, and appreciated at home and in school. Indeed, most students stated that teachers and other school staffs' sensitivity to their needs, interests, preferences, and individual differences influences their decision to remain at school. In the same manner, the findings obtained from teachers' response contended that unconditional love, care, and respect from the school community increases students' level of persistence at school. Relatively, parents responded that motivation makes learners resilient to go on with school despite the life challenges that disturb them. Motivation leads to persistence on the part of the student making learners more likely to continue with school until they complete (Birgen, 2017). In addition to students emphasized that the teacher's use of motivating phrases encourages them that they can make up to their full potentials in life despite all setbacks. Indeed, motivations inculcate instinct of perseverance to students hence their decision to continue with school until completion among students. Thus, the motivational supports students get from teachers and parents develop sentiments of perseverance toward the achievement of challenging goals among students. Thus the power of hope is very important in keeping an individual persist toward the achievement of their goals. Supporting these Hernandez et al. (2020) in their study done in Portuguese Universities commented that motivation leads to a higher level of resilience among students. They added that perseverance predicts educational accomplishment by encouraging students to value their hard work.

This implies that motivation increases students' determination to complete their studies. Thus, when students are motivated could not easily give up school hence their retention.

\section{Motivation creates a happier and enjoyable study atmos- phere}

The results of this study demonstrate that motivation contributes to students' retention as it makes the school environment enjoyable and happier place for students to stay. Most students who participated in this study stated that motivation makes them more excited to continue with the school as they find pleasure, happiness, and joy at school. Indeed, findings from open-ended questionnaires demonstrated that students are more likely to retain at school when they are fairly treated by their teachers, supported, given opportunities, recognized and valued, and appreciated.

Likewise, most parents emphasized that motivation makes learning a joyful activity among students, making them unsatisfied with school hence their retention. One of the parents stated that "motishahufanyawanafunzikufurahia shule na huwafanya watoto waweze kwendashulenikilasikuhivyokuendeleanamasomohadikumaliza". [Motivation makes students enjoy school and excited to attend school on regular basis hence their retention]. From the findings, it can be established that motivation makes students enjoy staying at school as they find the school a happier place for them. Hernik and Jaworska 
(2018) support the importance of motivation and joy in school arguing that teaching is an emotional task thus; it is of paramount activity for teachers to bring humor in school to increase students' concentration, engagement, and retention. The students who find themselves supported at school enjoy continuing with school and become aspiring to additional schooling (Smith et al. 2016). Again, Alizadeh (2016) stresses this arguing that when there is enjoyment for learners at school they could never drop out. Relatively Smith et al, (2016) add that satisfaction of students' needs and interests is the source of school enjoyment and retention. When a student feels happy and satisfied with his or her needs the motivation to continue with school increases (Al-Shara, 2015). Therefore, the feeling of satisfaction is of paramount importance in making students continue with school.

\section{Motivation develops the sagacity of school belongingness}

All participants noted that motivation develops a feeling of school ownership among students. Motivation creates a solidified social connection at school whereby there is shared trust between all members of the school community. Respondents and participants maintained that motivation develops a school culture where each learner takes school as his or her second home. Indeed, motivation creates a sense of family hood within a school community. Most students claimed that motivation makes them feel comfortable and free while at school as they find themselves physically and emotionally safe. This implies that students' physical and emotional safety influences their decision to remain at school. The feeling of safety while at school is the warrant for students' belongingness at school and their retention (Williams et al. 2018). Also, interviewees were of the view that the feeling of being accepted, cared for, valued, and loved creates strong ties between a student and his or her school. The interviewee's views were also in the bottom-line with the teachers 'response which indicated that students' feeling of being cared for and valued, as well as consideration of their interests and preferences in decision making, creates a sense of school ownership among them. Similar claims were also made by Interviewee $1(\mathrm{HoS})$ claiming:

Students' feeling of being loved, cared for, involved, and accepted by their teachers' matters in their decision to continue with school. Students need to have groups and friends to interact and socialize with daily. When they find the school environment with people who accept them, treat them fairly, love them, consider and listen to them despite their differences it is so hard for them to withdraw from school (Interviewee 1, August 27, 2020). This implies that adequate care,respect and love motivate students to continue with school. Students feel more comfortable to continue with school in an environment where they feel recognized and appreciated.

The qualitative study by Bouchard and Berg (2017) supports that individual students' acceptance and care builds a sense of school belonging. They added that schools and teachers should dedicate themselves toward caring and valuing individual learners despite their differences.

This means that when a school becomes a community where each member is loved and valued the students are most likely to stay there for the whole of their study period. Therefore, motivation strengthens students' desire to continue with school. It cements students to their school.

\section{Research Question Two}

The second research question endeavoured to identify motivational challenges facing public secondary school students in Rorya District. From the findings, it was clear that most of the students are faced with challenges such as inadequate learning facilities, long distance to and from school, categorization based on their academic merits, staying with hunger while at school, not being cared for and respected, lack of physical and emotional safety caused by incidents such as corporal punishment, negative attitude and comment from teachers, sexual harassment, superstitious beliefs, and witchcrafts all of which reduce their motivation to continue with school. The researcher presented the respondents with the table having six subsections indicating the statements and five subsections which were presented with ten views in which respondents were required to state their agreement on five points from the Likert scale. The sampled students were requested to put a tick $(\checkmark)$ where appropriate to show the extent they accept the statement indicating the motivational challenges affecting their retention at school. Their responses are tabulated in Table 4.

Note: $1=$ strongly disagree, $2=$ Disagree, $3=$ Moderate and 4=Agree, $5=$ Strongly Agree, $\mathrm{M}=$ Mean and $\mathrm{SD}=$ Standard Deviation. 
Table 4: Motivational challenges influencing low retention $(n=76)$

\begin{tabular}{|c|c|c|c|c|c|c|c|c|c|c|c|c|}
\hline \multirow[t]{2}{*}{ STATEMENT } & \multicolumn{2}{|l|}{1} & \multicolumn{2}{|l|}{2} & \multicolumn{2}{|l|}{3} & \multicolumn{2}{|l|}{4} & \multicolumn{2}{|l|}{5} & \multirow[t]{2}{*}{$\mathbf{M}$} & \multirow[t]{2}{*}{ SD } \\
\hline & $\mathbf{F}$ & $\%$ & $\mathbf{F}$ & $\%$ & $\mathbf{F}$ & $\%$ & $\mathbf{F}$ & $\%$ & $\mathbf{F}$ & $\%$ & & \\
\hline $\begin{array}{l}\text { Inadequate school necessities such } \\
\text { as uniform influence students' } \\
\text { school withdrawal }\end{array}$ & - & - & - & - & - & - & 26 & 34.2 & 50 & 65.8 & 4.66 & .478 \\
\hline $\begin{array}{l}\text { Less voice in decision making de- } \\
\text { motivate students }\end{array}$ & - & - & - & - & - & - & 36 & 47.4 & 40 & 52.6 & 4.57 & .499 \\
\hline $\begin{array}{l}\text { Poor academic performance re- } \\
\text { duce students' motivation to contin- } \\
\text { ue with school }\end{array}$ & 2 & 2.6 & 44 & 57.9 & - & - & 30 & 39.5 & - & - & 4.62 & .489 \\
\hline $\begin{array}{l}\text { Staying with hunger while at school } \\
\text { fuels their decision to leave school }\end{array}$ & - & - & - & - & - & - & 29 & 38.2 & 47 & 61.8 & 4.62 & .489 \\
\hline $\begin{array}{l}\text { Negative remark from teachers re- } \\
\text { duce students' motivation to contin- } \\
\text { ue with school }\end{array}$ & - & - & - & - & - & - & 29 & 38.2 & 47 & 61.8 & 2.76 & 1.018 \\
\hline $\begin{array}{l}\text { Long-distance to and from school } \\
\text { demotivate students from school } \\
\text { continuation }\end{array}$ & - & - & 4 & 5.3 & - & - & 16 & 21.1 & 56 & 73.7 & 4.63 & .746 \\
\hline $\begin{array}{l}\text { Sexual harassment demotivate stu- } \\
\text { dents from schooling }\end{array}$ & - & - & 3 & 3.9 & - & - & 22 & 28.9 & 51 & 67.1 & 4.59 & .696 \\
\hline $\begin{array}{l}\text { Corporal punishments by teachers } \\
\text { demotivate learners from schooling }\end{array}$ & - & - & - & - & - & - & 28 & 36.8 & 48 & 63.2 & 4.63 & .486 \\
\hline $\begin{array}{l}\text { An unattractive school environment } \\
\text { is associated with low motivation } \\
\text { among students. }\end{array}$ & - & - & - & - & - & - & 24 & 31.6 & 52 & 68.4 & 4.68 & .468 \\
\hline
\end{tabular}

\section{Source: Field Data (2020)}

Table 4 presents the quantitative findings on the motivational challenges leading to students' low retention in Rorya District public secondary schools. The students' responses indicated the students' agreement or disagreement levels on the statement explaining motivational challenges leading to low retention in their respective schools. The results indicated that all most all students agreed on the existence of those challenges in their schools. Table 4 presents that most of the participants are 73.7 percent strongly agreed that long distance to and from school reduces students' motivation to continue with school, 21.1 percent agreed and only 5.3 percent respondents disagreed that the distance to and from school does not reduce students' interest to continue with school. The second major challenge which had a higher score is sexual harassment whereby 67.1 percent of the re- spondents strongly agreed that sexual harassment reduces girl students' motivation to continue with school, 28.9 percent agreed and only 3.9 percent disagreed. Again, 63.2 percent of the students strongly agreed that corporal punishment strongly demotivates students from staying at school and 36.8 percent agreed with no one who disagreed with the statement. In the same manner, 68.4 percent of the respondents who participated in this study strongly agreed that an unattractive school environment reduces students' motivation to continue with school and 31.6 percent agreed and none of the respondents had shown disagreement with the statement. Again, 61.8 percent of the respondents strongly agreed that hunger and negative teachers' remarks demotivate students from continuing with school and 38.2 percent agreed. Furthermore, 65.8 percent of the respondents strong- 
ly agreed that inadequate school necessities reduce students' motivation to continue with school, and 34.2 agreed. Moreover, 52.6 percent of respondents strongly agreed that less voice in decision making demotivates students and 47.4 percent also agreed.

However, the results obtained on the influence of poor academic performance on students' motivation to continue with the school were quite controversial as most students disagreed that poor academic performance demotivates them from continuing with school 2.6 strongly disagreed, 57.9 percent disagreed while only 39.5 percent agreed that poor academic performance is associated with low retention. This is contrary to Moore (2017) in his study in Tennessee ascertaining low grades as a motivational challenge influencing low retention. This implies that students score in the examination does not reduce their motivation to retain at school unless they were used by peers and teachers as a tool to embarrass them.

\section{Research Question Three}

The third research objective sought to find out the strategies that could be used to mitigate motivational challenges hindering students' retention in Rorya District public secondary schools. The study came up with various strategies highlighted by the respondents and participants to motivate students to remain at school until completion. All respondents and participants who participated in this study stressed that for the students to stay at school until completion they should be assured of their physical and emotional safety. The identified strategies includethe provision of adequate school facilities, creation of sensitive, friendly, and supportive learning environment, provision of guidance and counseling service, provision of opportunity for students to participate in decision making, Active parenting role, provision of lunch program for students, the abolition of corporal punishments, the establishment of sexual harassment prevention and reporting mechanism.

\section{CONCLUSION}

To this end, the study concludes that motivation has a significant impact on students' retention. The study shows that motivation is the heartbeat and roadmap to students' retention in public secondary schools. It gives students a pathway toward their full potential. Again, the study identified that motivation varies from one student to another as what motivates one learner might not work for the other. Thus, motivation is based on satisfied and unsatisfied needs. This means to motivate students to retain at school their individual needs have to be satisfied first. However, this study unveiled that despite the introduction of free education in Tanzania, still many students quit school due to unsatisfied and ceased needs. This means that there are a lot of uncovered critical motivational issues forcing students out of school in public secondary schools. Therefore, despite the increase in enrolment in public secondary school, the study results show that there are many motivational challenges influencing school withdrawal among students. In other words, all educational stakeholders have failed to retain students at school until completion. It was also revealed that educational leaders are concerned with examination performance only and they are ignoring many other aspects necessary for students' retention at school. Hence, based on these findings, there is evidence that Rorya District public secondary school students' are mired with various challenges such as inadequate school necessities, unfriendly school environment, sexual harassment, witchcraft, and distance from home to school, all of which makes students uncomfortable to continue with school, requiring immediate strategic intervention. Indeed the motivational challenges of students when well addressed can lead to significant improvement in the retention of the students. However, all educational stakeholders inclusive of teachers, parents, government, and NGOs concerned with education should put effort into the importance of motivation in enhancing students' retention. Parents and teachers should create a supportive environment increasing students' interest in schooling. Again, they should assist in satisfying the individual students' motivational needs such as food, safety, belongingness, interests, respect, admiration, recognition, appreciation, and the possibility to advance to their full potential.

\section{RECOMMENDATIONS FOR PRACTICE}

\section{Recommendation for the Ministry of Education, Science, and Technology}

The Ministry of Education, Science, and Technology in Tanzania should provide sufficient resources to create a supportive teaching and learning environment that motivates students' retention in secondary schools. The ministry should make sure that schools have attractive and adequate school facilities such as classrooms, gender-sensitive washrooms, textbooks, and other teaching-learning materials that enhance motivation among students.

Moreover, the Ministry should make sure that they develop policies that prohibit corporal punishments at public second- 
ary schools. Again, the ministry should develop a mechanism at each school that gives chance students to report challenges associated with sexual abuse and harassment.

Also, the government should constantly provide seminars and workshops to update teachers on the importance of motivation in enhancing students' retention. Teachers should be reminded of the best ways to motivate their students.

The study recommends teachers to motivate their students by giving them a voice in decision making, valuing their interests, socializing, joking, and laughing with them. Again, this study recommends the teaching staff and non-teaching staff to fairly treat students with love and care. The findings of this study require the teachers to create a friendly and supportive environment that motivates students. Inside the classroom, teachers should use differentiated approaches in teaching so that they can meet learners' diverse motivational

[1] Adam, S., Adom, D. \&Bediako, A. B. (2016). The major factors that influence basic school dropout in rural Ghana: The case of Asunafo South District in the BrongAhafo Region of Ghana. Journal of Education and Practice, 7(28), 1-8.

[2] Berger, J., Girardet, C., Vaudroz, C. \&Crahay, M. (2018). Teaching experience, teachers' beliefs and self-reported classroom management practices: A coherent network. Sage Journal1 (12), 1-12.https://doi: 10.1177/2158244017754119.

[3] Birgen, M.C. (2017). Motivating factors that enhance students' academic performance: A case of Saint Michael's Tulwopngetuny secondary school in UasinGishu, County Kenya. Journal of Research and Method in Education, 7(5), 44-49.

[4] Creswell, J.W. (2012). Educational research planning, conducting and evaluating quantitative and qualitative research $4^{\text {th }}$ Ed. Pearson.

[5] Crosling, G. (2017). Student retention in higher, education: A shared Issue. Springer.

[6] Fan, W. \&Wolter, C.A. (2014). School motivation and high school dropout: The mediating role of educational expectation. British Journal of Educational Psychology, 84(1)22 39.

[7] Human Rights Watch (2017). I had a dream to finish school: Barriers to secondary education in Tanzania. Human Rights Watch. https://www.hrw.org/report/2017/02/14/.

[8] James, A.M., Simiyu, A.M. \&Riechi, A. (2016). Factors affecting subsidized Free Day Secondary Education in enhancing learners' retention in secondary schools in Kenya. Journal of Education and Practice, 7(20), 49-55.

[9] Kinisa, O.R.G. (2019). Effectiveness of educational policy in curbing school dropout in secondary schools in Tanzania: A case of Dodoma city. International Journal of Scientific and Research Publications, 9(5), 129 - 159. needs and make them enjoy the lesson. Again, the teacher while teaching should make the lesson relevant to students' interests and needs. They should use examples that exist in the students' real and immediate environment. In addition to that teachers should develop a professional and friendly relationship with each student by freely interacting with them, listening to them, playing with them, and having inspirational stories with them.

The parents should boost children's interest to continue with the school by creating an academic friendly learning environment at home. They should give their children the required school necessities which add to their school interest. Also, parents should give their children enough time to rest or sleep at night by not overworking them with home chores after school.

\section{REFERENCES}

[10] Kipyego, M.A. (2016). Government subsidies and their influence on student access and retention in secondary schools in Nandi north sub-county, Kenya [Unpublished Master dissertation]. Kisii University.

[11] Krstic, K., Ilic, I.S. \&Videnovic, M. (2017) Student dropout in primary and secondary education in the Republic of Serbia. Journal of Psychology Research, 20(1), 27 - 50.

[12] Kurebwa, M. \& Wilson, M. (2015). Drop out in the primary schools, a cause for concern: A case of Shurungwi south resettlements primary schools 2006-2013. International Journal of Education and Research, 3(4), 505-514.

[13] Lockett, C. \&Cornelous, L. (2015). Factors contributing to secondary school dropouts in an urban school District. Research in Higher Education Journal, 29(0)1-15.

[14] MoEST \& UNICEF (2018) Global Initiative on out of school children: Tanzania, Verification of the out of school children study. UNESCO

[15] MoEST (2016).Basic education statistics in Tanzania. Ministry of education science and technology.

[16] MoEST (2018). Education sector development plan 2016/2017-2020/2021 in Tanzania mainland. Education sector development committee (ESDC).

[17] Moore, A.K.P. (2017). Dropped - out: Factors that cause students to leave before graduation [Unpublished doctoral Dissertation].Carson - Newman University, Jefferson, Tennessee, U.S.A.

[18] Nzina, J.W., Mulwa, D.M., Peter, K, R. (2019). Socio - economic factors influencing female students' retention in public secondary schools in Mukaa sub - country, Makueni country, Kenya. International Journal of Education and Research, 7(9), $297-310$.

[19] Orotho, J.A. (2014). Policies on free primary and secondary education in East Africa: Are Kenya and Tanzania on course 
to attain education for all (Efa) goals by 2015? Journal of Humanities and Social Science, 19(1), 11-20.

[20] Ouma, D.H., Ting, Z. \& Pesha, J.C. (2017). Analysis of the social economic factors that contribute to the children school dropout in artisanal small-scale gold mining communities of Tanzania. Journal of Education and Practice, 8(14), 71-78.

[21] Raymond, E. \& Lesego, W. (2017). Contributing factors to learner dropout in public school in NgakaModiri-Molema District. The Social Sciences, 12(3)459-466.

[22] Samuel, S.M., Mulwa, D.M., Migosi, J.\& Kamau, L.M. (2017) Influence of school based factors on educational wastage in public secondary schools in Machakos country Kenya. International Journal of Humanities and Social Science, 7(1), $257-262$.

[23] Soilemetzidis, I. \& Dale, C. (2013). Student retention in UK higher education: Exploring the link between entry grades and attrition trends. European Academic Research, 1(8), 2-25.

[24] Solak, E. (2012). Exploring the role of motivational factors in the academic achievement of EFL Learners. ELT Research Journal, 1(4), 240 - 254.

[25] Subedi, D. (2016). Explanatory sequential mixed method design as the third research community of knowledge claim. American Journal of Educational Research, 4(7), 570-577.

[26] Tasgin, A. \& Tunc, Y. (2018). Effective participation and motivation: An investigation of secondary school students. World Journal of Education, 8(1), 58-74.

[27] The World Bank (2017). International development association programme paper on a proposed additional credit in the amount of SDR 59 million (US \$ 80 million equivalent) to the united republic of Tanzania for an education program for results. Education Global Practice Africa Region.

[28] Williams, S., Schneider, M., Wornell, C. \& LonghinrichsenRohling, J. (2018). Student's perceptions of school safety: It is not just about being bullied. The Journal of School Nursing, XX(X), 1-12.https://doi: 10.1177/1059840518761792.

[29] Yilmaz, E., Sahi, M., \&Turgut, M. (2017). Variables affecting student motivation based on academic publications. Journal of Education and Practice, 8 (12), 112-120. 